\title{
The Role of Spirit Messages in African Conflicts the Case of Joseph Kony and the Lord's Resistance Army in Uganda
}

\author{
Paul Sturges* \\ Department of Information Science, Loughborough University, Leicestershire LE11 3TU, UK
}

\begin{abstract}
Whilst African civil conflicts are usually presented in the media as either political struggles, terrorism or mere banditry, in some at least there is a substantial spiritual element. Conflicts Zimbabwe, Mozambique and elsewhere in African have been shown to contain highly significant contributions from spirit forces intermediated by mediums, traditional healers, and prophets. Aspects of the Acholi insurgency in Northern Uganda have been initiated and led by spirit mediums, notably Alice Auma and Joseph Kony. Because Kony's career as an insurgent leader has been marked by atrocity and the lack of an explicit political programme, he has often been dismissed as a terrorist. It is argued here that he at least deserves the status of 'social bandit' as defined by Hobsbawm, and that his role as a voice for spirit messages is still a significant factor. It is concluded that without recognition of the role of spirit messages in African conflicts these conflicts will be imperfectly understood and their resolution will be correspondingly more problematic.
\end{abstract}

Keywords: Civil conflict, spirit messages, Uganda, Lord's Resistance Army, Joseph Kony.

\section{INTRODUCTION}

A news item in September 2009 [1] reminded the reader that the insurgency or banditry, of the Ugandan Lord's Resistance Army (LRA) of Joseph Kony had retained some of its spiritual dimension after two decades of massacre, mutilation, abduction, regional political manoeuvring, and relentless guerrilla warfare. Two of Kony's 'wives' are quoted as saying that Kony had the power to protect them from the effect of bullets, and that he could predict when the Ugandan army (the UPDF) would attack. In December 2008 when he and his forces were established at a base in the Democratic Republic of the Congo, he was receiving messages from angels and from God that enabled him to evade the airborne Operation Lightning Thunder that was directed against him by the UPDF, allegedly with US guidance and logistical backup. One of the wives, quoted in the same article, said of him 'People have written that he is an evil spirit. That is nonsense. He has the power to cast out evil spirits.' In the occasional reporting of his activities in the press of the industrialised countries Kony is portrayed as a monster. It is less common to see it acknowledged that his original status was that of a spirit medium, and that this element has never gone away.

Conflicts in Africa, whether they have been colonial wars of liberation, civil wars, and other post-colonial conflicts they have often, maybe always, shared this spiritual dimension. To trace the spiritual element across the conflicts of the last 50 or 60 years is far beyond the scope of this short review, but by concentrating on Uganda the role of spirit communication can be illustrated quite effectively. First of

*Address correspondence to this author at the Department of Information Science, Loughborough University, Leicestershire LE11 3TU, UK; Tel 00 441332 863280; E-mail: r.p.sturges@lboro.ac.uk all, it is probably necessary to point out that the spiritual is always much closer to the surface in African life than it is in Europe and North America. The casual traveller or unobservant temporary resident can miss this. However, one does not have to live for very long in an African country to be aware that in the villages (and in the cities too) there is communication activity that does not fit the expected categories. There is always the presence of traditional healers in the community; there are rumours that abductions and unexplained deaths had some connection with magic-making; and evidence of activities of secret societies is there if one is alert to what is happening round and about. As Doom and Vlassenroot [2 p.17] say of Kony's own Acholi people in Northern Uganda "The Acholi world is a spiritual community, densely populated with spirits, forces and powers." Basically the same could be said of almost any African people and Boddy [3] gives an idea of the scope of the topic. But conflict has the capacity to bring this much closer to the surface. Before looking at Northern Uganda in rather more detail, examples from one or two other conflicts will illustrate the widespread significance of spirit messages.

\section{THE ROLE OF SPIRIT MESSAGES}

Spirit messages can be found playing an important part in preparing a people for war, in the detailed conduct of that war, and also in determining the outcome of a war. Prophesy as a means of preparing a leader can be seen in the case of Joshua Nkomo in the Zimbabwe war of liberation. The independent country which emerged from the struggle in 1980 was dominated by the Shona majority, of whom the president Robert Mugabe is one, and by ZANU their overwhelmingly Shona party. However, the role of the minority Ndebele from the south west of the country and their ZIPRA guerrillas should not be overlooked. Some people actually claim that ZIPRA with its Ndebele military tradition carried 
the brunt of the fighting, whilst the more political Shona reaped the benefits. In 1953 a young Nkomo visited the Dula shrine in the Matopos area with two associates. The voice of Mwali, the spirit of the shrine, turned away everyone else who was there and prophesied direct to Nkomo, saying:

"You son of Nyangolo, great-son of Maweme, you will lead this nation. When you go into the river, I'll be with you, into the seas I'll be with you. When you climb trees I'll be with you. When you hide among the small shrubs I'll be with you. Wherever you are I'll be with you until this war is over. Nobody will touch your body. I'll fight with you, let's go to the war together" [4, p.43].

The Ndebele contribution to the liberation struggle has generally been regarded as less spiritually inspired than was the case with the Shona, but here we have a magnificent prophesy that linked Nkomo and his role in the struggle with a spirit and a site of traditional religion established long before the Ndebele entered the land at the end of the nineteenth century.

Ranger [5, p. 14] claims that "Peasant participants in Zimbabwe's guerrilla war fought for their lost lands and drew heavily upon symbols of their past and on rural religion to sustain them". The close connection between the Shona guerrilla effort and spirit mediums has been documented in great detail in Lan's study of the conflict [6]. Warnings, advice and tactical guidance were all provided to Zimbabwean guerrillas at various times by the spirits of ancestors, through the agency of mediums.

"Belief in the participation of the ancestors was elaborated into a system of ritual practices believed to place the combatants under their protection. While on active service within the borders of Zimbabwe, the guerrillas were not allowed to have sexual intercourse, they were not allowed to kill wild animals in the forest and they were not allowed to eat certain foods" (Lan, p.xvii).

Such practices are essentially similar to those found in other regions and other conflicts.

In Lan's account the close relationship between the guerrillas and the communities within which they move was structured and guided by the ancestors through their mediums into a harmonious and mutually accepted pattern. This view has not been universally accepted and Kriger [7] has suggested, on the basis of extensive oral history work, that coercion was an essential tool of the guerrillas. From this perspective the guerrillas are seen in a less favourable light: people avoided working for them if they could, and cooperation was often more to gain local advantage than for ideological reasons, spiritual reasons or commitment to national liberation. This does not, however, negate the perception that in both rhetoric and everyday practice the spiritual dimension was an ever present factor in the conflict.

The post independence struggle in Mozambique between the Frelimo government and the South African backed Renamo rebels exhibits some interesting comparisons. Frelimo is often described as an ideological movement, built on Marxist principles and not concerned with traditional values. As Finnegan puts it 'Traditional society was feudal. Religion was obscurantismo. Chiefs and curandeiros [traditional healers] were shunted aside. The brave new day of scientific socialism had dawned' [8, p.117]. They are said to have acted as if Mozambique was a tabula rasa on which they could write a new history. This rather parallels the secularism of the Rhodesian government pre 1980, but Renamo showed respect for tradition, in a way that had much more in common with ZANU in Zimbabwe. In the areas where they achieved control, they restored local chiefs to administrative roles, and rehabilitated the neglected village elders. Even more important than this was their acceptance of the religious powers. Possibly as many as $70 \%$ of Mozambicans were attached to traditional religion, rather than either Christianity or Islam, and Renamo responded directly to this.

Renamo was willing to work in cooperation with not only the curandeiros, but espiritas (spirit mediums), feiticeiros (witch doctors) and profetas (prophets). Finnegan's (p.64) enquiries suggested that "Renamo's alliance with the supernatural also seemed to be accepted at face value by many ordinary Mozambicans. In every part of the country I visited, I heard people say that the matsangas [Renamo rebels] were bulletproof and that they were immortal." Frelimo was, however, not necessarily as detached from the spiritual dimension as Finnegan asserts. The assistance of Manuel Antonio, who was in receipt of messages from Christian spirits, was utilised by Frelimo in the fight against Renamo and their traditionalist allies [9]. The conflict could in fact be seen as between a socialist movement prepared to countenance aspects of Christianity (Frelimo), and a more traditional movement listening to the messages of the ancestors (Renamo). How far this war of the spirits made a difference to the eventual resolution of the conflict is virtually impossible to assess. However, the spiritual element might sometimes be decisive. For example, a suggestion is sometimes heard that the Biafran military effort collapsed in the Nigerian Civil War of 1967-70, not when starvation and shortage of materiel became impossibly acute, but when the spirit mediums attached to military units were deprived of their positions of influence.

\section{THE ACHOLI INSURGENCY IN UGANDA}

The political and military content of the conflict in Northern Uganda has been dealt with by a number of writers Apuuli [10], Jackson [11], Van Acker [12], Vinci [13], Vinci [14], and Sturges [15]. Whilst in similar discussions of other conflicts the spiritual might be forgotten or ignored, in Northern Uganda it cannot be. So as to focus fully on the spiritual aspects, this article will not go over the background again in any detail, but a brief summary of key factors is needed. President Yoweri Museveni is a southern president who overthrew an Acholi dominated regime in 1986. Acholi soldiers retreated north to their homeland, or across the border into Sudan, quite realistically fearing massacre at the hands of troops loyal to the government. Their subsequent efforts were directed into an unsuccessful rebellion under the name of the Uganda People's Democratic Army (UPDA). The failure of this and other contemporary insurgencies left the region impoverished and demoralised, with over one million people in Internally Displaced Persons' camps living in fear of the state and its armed forces.

The failure of the UPDA and other conventional politi$\mathrm{cal} /$ regional movements was immediately followed by the emergence of the Holy Spirit Movement (HSM) of Alice 
Auma [16]. She is usually referred to as Alice Lakwena, after her chief spirit adviser. While the structures of spiritual communication employed by Alice and other spirit mediums are rooted in tradition, that tradition has been expanding and changing. Behrend and Luig [17] set this in the context of a burgeoning of spirit possession cults worldwide in the late twentieth century. African spirits with European names who comment on a world of machines and modern global culture have been dominating this development. They generally adopt Christian viewpoints, effectively reinforce modernity, and can be seen as in opposition to the traditional, local spirits representing 'witchcraft'. The Renamo-Frelimo spirit conflict, mentioned earlier, exemplifies this contest. Christian influences are visible in the practices and beliefs Alice adopted. The traditional spirit mediums and healers were known as ajakwa, but Alice adopted the identity of a nebi (prophet in the biblical sense), spending forty days and forty nights in the wilderness at some point during 1985.

After the success of Museveni's rebellion, she not only carried out healing rituals for the retreating Acholi soldiers, but in effect offered an explanation of defeat [18]. The defeated were impure, but could be purified by following rules and practices that she set out. In addition, witches and other bad people were to be driven out by the same means. The rules that Alice laid down for her followers were couched in biblical style, but bear strong resemblances to the rules set out by the Zimbabwean spirit mediums in the liberation struggle, for instance.

"The rules vary somewhat between testimonies but are consistent in their prohibition of wearing lucky charms, consulting other healers and mediums, sexual intercourse, alcohol, tobacco and certain foods (white ants, pork, and sometimes mutton). Other prohibitions that appear frequently are on food cooked in saucepans, eating with anyone who has not been anointed, killing snakes, becoming angry, and theft" $[19$, p. 376].

Later a rule that "Thou shalt have two testicles, neither more nor less" was added, although Allen speculates that this might have had humorous intent. Alice mobilised the Acholi in an initially successful insurgency that pitted warriors protected by anointment with shea butter oil and holy water, and using rocks that were to turn miraculously into grenades, against tanks and artillery. The bloody defeat of the HSM's invasion of the south at Jinja and Alice's escape (on a bicycle it is said) did not, however, bring an end to what might seem to outsiders the Acholi recourse to the irrational.

From the wreckage of the HSM came the movement that soon adopted the name Lord's Resistance Army, led by Joseph Kony, reputedly a cousin of Alice's. Kony also received spirit messages. In the beginning some came from Lakwena himself, as well as from others including Juma Oris, Silli Silindi, Silver Koni, King Bruce and Major Bianca who dealt with specific aspects of the movement's activity, including battle tactics and intelligence matters [20]. Like Alice, Kony established 'yards' in which the purification of his followers and the reception of his messages could take place. Kony also stressed the Ten Commandments and other Christian elements in his messages. In the 1990s when he had spent much time across the border in Sudan, allegedly subsidised by the Sudanese government to counter the Christian rebels of southern Sudan (the Sudan People's Liberation Army, or SPLA), he also introduced Muslim elements. Traditional religion is seldom a hermetic system and in times of turmoil it is likely to be more receptive to new influences. In all of this Kony is a recognisable part of the global movement of spirit possession cults mentioned earlier. If we seek to place him on the scale of modernist/Christian to traditionalist/sorcerer, we see that he has shifted over the years. The name of his movement still invokes the Christian God, as does some of the Christian terminology that he and his associates still use.

The problem with Kony is that while he remains, at least in the view of those close to him, a conduit for spirit communication, he is also something else. That something else is, according to one's viewpoint, an Acholi freedom fighter, an accomplished practitioner of guerrilla warfare, a 'social' bandit, a monstrous criminal, or, quite simply, a madman with the capacity to wreak untold horrors on the innocent of several Central African countries. In its despair, the Acholi people have felt a need for protectors and leaders. A few still seem to see Kony in this light.

Despite all he has done, much of it inflicted on his own people, there remains a grudging perception of him as the spiritually guided leader that they needed. His ability to move his columns of a few hundred men and child soldiers against widely scattered targets at terrifying speed and with horrible effectiveness certainly qualifies him as a guerrilla fighter of the highest ability. The government calls him a terrorist and the International Criminal Court indicted him for war crimes in 2005, but the sense that his crimes originate in the grievances of the people and that he still enjoys some residual respect may qualify him to fit Hobsbawn's definition of social bandits:

"They are peasant outlaws whom the lord and state regard as criminals, but who remain within peasant society, and are considered by their people as heroes, as champions, avengers, fighters for justice, perhaps even leaders of liberation, and in any case as men to be admired, helped and supported" [21, p. 17].

Criminal Kony is, in the sense that under his orders, murder, mutilation, rape, abduction, destruction and theft have been carried out in horrible abundance: social bandit he may be.

But although it seems that he has been subsidised by foreign players, including the government of Sudan, and although his movement survives by predation, it seems not to be wholly a predator movement such as those that have grown rich by plundering the minerals and diamonds of countries like Sierra Leone. Kony may also be mad. The conduct of his movement, and the monstrous rages and shifts of mood that those who have talked with him describe, is certainly mad. Probably the best summary of Kony is that in some way or other he overlaps all of these categories. The road on which the messages of the spirits set him has led to the unhappiest of outcomes, but he is still in some way their chosen vehicle. 


\section{CONCLUSIONS}

When we choose to explore the spiritual world we cannot expect that it will be a realm of light, inhabited by angels and filled with heavenly music. In the spirit world the purifying influences of some spirit entities come into conflict with the more mischievous forces of witchcraft and sorcery. In the material world parallel conflicts also take place. In wars and civil conflicts the spirits struggle alongside those to whom they reveal their messages so as to achieve worldly as well as spiritual goals. In the African conflicts discussed above, the spiritual dimension is woven into the fabric of events and into the consciousness of participants in a way that is not ostensibly the case in the industrialised countries. And yet, priests and religious leaders of Europe and North America still pray for the success of their nations' armies against enemies in formally declared wars and anti-insurgency campaigns. Warfare and the spiritual life are universally bound together, but in Africa the linkage is visible, acknowledged and should never be ignored. In the rationalist/Christian cultures of the industrialised countries it is exceptionally hard to come to terms with such an alien-seeming phenomenon. It challenges our paradigms and demands a rethinking of our attitudes. Yet if we do not respond, our thinking on how to help bring peace and justice to some of the most benighted regions of the world will be less than fully effective.

\section{REFERENCES}

[1] Rice X. 'Joseph Kony just kills people for nothing': fugitive rebel spreads terror in the bush. Guardian (UK) 2009: pp. 24-5.

[2] Doom R, Vlassenroot K. Kony's message: a new koine? The Lord's Resistance Army in Northern Uganda. African Aff 1999; 98: 5-36.

[3] Boddy J. Spirit possession revisited: beyond instrumentality. Annu Rev Anthropol1995; 23: 407-34.
[4] Ranger T, Ncube M. Religion in the guerrilla war: the case of Southern Matebeleland. In: Bhebe, N. and Ranger, T. Eds. Society in Zimbabwe's liberation war. Oxford: James Currey 1996.

[5] Ranger T. Peasant Consciousness and Guerrilla War in Zimbabwe: a Comparative Study. Oxford: James Currey 1985.

[6] Lan D. Guns and rain: guerrillas and spirit mediums in Zimbabwe. Oxford: James Currey 1985.

[7] Kriger N. Zimbabwe's guerrilla war: peasant voices. Cambridge: University Press 1992.

[8] Finnegan W. A complicated war: the harrowing of Mozambique. Berkeley and Los Angeles: University of California Press 1992.

[9] Wilson K. Cults of violence and counter violence. J Southern African Stud 1992; 18(3): 527-82.

[10] Apuuli KP. The International Criminal Court and the Lord's Resistance Army insurgency in Northern Uganda. Criminal Law Forum 2004; 15: 391-409.

[11] Jackson P. The march of the Lord's Resistance Army: greed or grievance in Northern Uganda? Small Wars Insurgencies 2002; 13(3): 29-52.

[12] Van Acker F. Uganda and the Lord's Resistance Army: the new order no one ordered. African Aff 2004; 103: 335-57.

[13] Vinci A. The strategic use of fear by the Lord's Resistance Army. Small Wars Insurgencies 2005; 16(3): 360-81.

[14] Vinci A. The 'Problems of Mobilization' and the analysis of armed groups. Parameters 2006; 36(1): 49-62.

[15] Sturges P. Information and communication in bandit country: an exploratory study of civil conflict in northern Uganda 1986-2007. Inf Dev 2008; 24(3): 204-11.

[16] Behrend, H. Alice Lakwena and the Holy Spirits War in Northern Uganda. London: James Currey 2003.

[17] Behrend H, Luig, U. Introduction. In: Behrend, H. and Luig, U. Eds. Spirit possession: modernity and power in Africa. Oxford: James Currey 1999. xiii-xxii.

[18] Allen T. Trial justice: the International Criminal Court and the Lord's Resistance Army. London: Zed Books 2006.

[19] Allen T. Understanding Alice: Uganda's holy spirit movement in context. Africa 1991; 61(3): 370-99.

[20] Behrend H. Power to heal, power to kill: spirit possession and war in Northern Uganda (1986-1994). In: Behrend H, Luig U, Eds. Spirit possession: modernity and power in Africa. Oxford: James Currey 1999; pp. 20-33.

[21] Hobsbawm, E. Bandits. London: Weidenfeld and Nicolson 1969. 